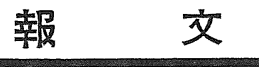

\title{
土佐産“せんだん”の実の脂肪酸について
}

\author{
平尾子之吉・亀 岡 弘 -今田健 夫 - 山本力生 \\ 近畿大学理工学部 (大阪府布施市小若江 321)
}

\section{On the Fatty Acid Constituent of Sendan (Melia japonica, G. Don) Seed Oil from Tosa Province}

Nenokichi Hirao, Hiromu Kameoka, Takeo Imada and Rikio Yamamoto

Faculty of Science and Engineering, Kinki University

(321, Kowakae, Fuse-shi, Ōsaka)

The Sendan seeds were collected in Tosa province at winter, and were extracted with light petroleum ether. The yield of oil was $4.7 \%$ and it had following constants : $d_{4}^{25} 0.9265, n_{\mathrm{D}}^{25} 1.4796$, A.V. 8.3, S.V. 223.4 and I.V. 80.6.

The oil was saponified with usual method, and mixed acid was obtained with $70.0 \%$ yield, which had following constants : $d_{4}^{30} 0.9369, n_{\mathrm{D}}^{30} 1.4743$, N.V. 213.6 and I.V. 96.4.

Separation was made byPb salt-alcohol method into solid and liquid acids, which were esterified with methanol and hydrochloric acid, and were fractionated in vacuum. Each fraction was examined for its component, and by means of gas chromatography it was characterised for the presence of caprylic, capric, lauric, myristic, palmitic and stearic acid as saturated fatty acids, and oleic and linoleic acid as unsaturated acids.

\section{1 緒言}

せんだん (Melia japonica, G. Don) は本邦の四国, 九州, 小笠原, 琉球などに産する落葉喬木で, 九州産の 材 ${ }^{1)}$ ，東京産の樹皮 ${ }^{2}$ について簡単に調查した報告があ る。

また種子については水分, 含油率 ${ }^{3)}$, 鹿児島産の果 実 ${ }^{4)}$ の粗タンパク，粗脂肪あるいは核灭分，糖分などに ついての簡単な報告があるのみで，ほかに詳細な報告が ないので研究に着手し, 脂肪酸成分を明らかにしたので 報告する。

\section{2 実験とその結果}

\section{$2 \cdot 1$ 油脂の採取}

せんだんの果実は土佐産で昭和 34 年 12 月採取した。 乾燥したものに油分は大部分核内に存在するので, 乾燥 試料を磁製の乳鉢で粉砕しソックスレー抽出器を用い

Table-1 Extract of oil.

\begin{tabular}{c|c|c|c|c|c}
\hline Sample & Solvent & $\begin{array}{c}\text { Sample } \\
\text { weight } \\
(\mathrm{g})\end{array}$ & $\begin{array}{c}\text { Extrac- } \\
\text { ted tim } \\
\text { (hr) }\end{array}$ & $\begin{array}{c}\text { Crude oil } \\
\text { weight } \\
\text { (g) }\end{array}$ & $\begin{array}{c}\text { Crude } \\
\text { oil yield } \\
(\%)\end{array}$ \\
\hline Crush fruit & $\begin{array}{c}\text { Petroleum } \\
\text { ether }\end{array}$ & 32 & 72 & 1.50 & 4.68 \\
Seed & $\prime \prime$ & 20 & 72 & 1.36 & 6.82 \\
$\begin{array}{c}\text { Fruit rind } \\
\text { and meat }\end{array}$ & $\prime \prime$ & 12 & 72 & 0.17 & 1.38 \\
\hline
\end{tabular}

て石油エーテルで抽出した。

粉砕果実 $5 \mathrm{~kg}$ を石油エーテルで抽出し, $235 \mathrm{~g}$ の粗 油脂を得た。粗油脂中にエーテルーアセトンに不溶のも のが存在するかどうかを検するために，その $200 \mathrm{~g} に エ$ 一テル $200 \mathrm{~m} l$, アセトン $300 \mathrm{~m} l$ の混合物を加えて溶解 し， $24 \mathrm{hr}$ 放置したが エーテルーアセトンに不溶のもの はほとんど認められず, 少量の水分のみ含有されるので 溶剤を留去して, 水分も共に留出させた。最後に減圧に して残存する微量の溶剤および水分を除去し, 油脂とし て $189 \mathrm{~g}$ を得た。粗油脂中の不純物はほとんど水分で あり，また油脂の色調にも変化が認められなかった。油 脂の性状を Table-2 に示す。

Table-2 Characteristic of oil.

\begin{tabular}{c|c|c|c|c|c}
\hline A.V. & S.V. & I.V.(Wijs) & $d_{4}^{25}$ & $n_{\mathrm{D}}^{25}$ & Ash(\%) \\
\hline 8.3 & 223.4 & 80.6 & 0.9265 & 1.4796 & 0.097 \\
\hline
\end{tabular}

\section{2 ケン化物亡不ケン化物の分離}

油脂 $150 \mathrm{~g}$, 水酸化力リウム $45 \mathrm{~g}$, エタノール $750 \mathrm{ml}$ を用いて $3 \mathrm{hr}$ 加熱し, 水中に注加し, エーテル $500 \mathrm{ml}$ ずつで 3 回抽出し，エーテル層を合してエーテル溶液を 無水硫酸ナトリウムで乾燥した後エーテルを留去して, 不ケン化物として $37.5 \mathrm{~g}$ を得た。他方エーテル不溶の ケン化物層は希塩酸で弱酸性とし, エーテル $500 \mathrm{ml}$ ず つで 2 回抽出し，中性になるまで水洗し，無水硫酸マグ 
ネシウムで乾燥の後エーテル 溶液を合してエーテルを 留去し，ケン化物として $105.0 \mathrm{~g}$ を得た。その定数は Table-3 のようである。

Table-3 Constants of saponification snbstance.

\begin{tabular}{c|c|c|c}
\hline$d_{4}^{30}$ & $n_{\mathrm{D}}^{30}$ & N.V. & I.V.(Wijs) \\
\hline 0.9369 & 1.4743 & 213.6 & 96.4 \\
\hline
\end{tabular}

Table-3 の結果と Table-2 の定数を比較すると, Table-3 の中和価が小さく，ヨウ素価が多少大きくな っていることが恐められる。てれは後述する 2.5 の飽和 酸の検索から $\mathrm{C}_{8}$ - 酸が珰められたように低級の脂肪酸 が存在することから，乙の分離の段階におけるケン化物 の水中注加ならびに水洗の操作において，てれら低級脂 肪酸をごく少量損失したのではないかと考えられるが， 本研究においてはてのものについて検討しなかった。な お不ケン化物についても今回は検討しなかった。

\section{$2 \cdot 3$ 飽和酸亡不飽和酸の分離}

常法による鉛塩ーエタノール法を用いた。すなわち混 合脂肪酸 $96.0 \mathrm{~g}$, エタノール $500 \mathrm{ml}$, 酢酸鉛 $75 \mathrm{~g}$, 氷 酢酸 $6 \mathrm{~m} l$ を用いて行ない, 飽和酸部 $12.0 \mathrm{~g}$, 不飽和酸 部 $84.0 \mathrm{~g}$ を得た。これらの定数は Table-4 のようで ある。

Table-4 Constants of saturated and unsaturated acids part.

\begin{tabular}{c|c|c|c|c}
\hline Sample & $d_{4}^{30}$ & $n_{\mathrm{D}}^{30}$ & S.V. & $\begin{array}{c}\text { I.V. } \\
(\text { Wijs })\end{array}$ \\
\hline Saturated acids part & - & - & 233.6 & 4.6 \\
Unsaturated acids part & 0.9440 & 1.4802 & 198.7 & 97.8 \\
\hline
\end{tabular}

$2 \cdot 4$ 不飽和酸部中からオレイン酸系列の分離

リチウム塩ーエタノール法によって行なった。2.3で分 離した不飽和酸部 $80.0 \mathrm{~g}$ を無水エタノール $230 \mathrm{~m} l$ に 溶解し, 水酸化りチウム $7.3 \mathrm{~g}$ を溶解した水溶液 $230 \mathrm{ml}$ を加えて放置し，析出したりチウムセッケンはロ別し， $50 \%$ エタノールで洗浄し，不溶性リチウム塩を塩酸で 分解してエーテルで抽出し, エーテル溶液は中性になる まで水洗した後無水硫酸マグネシウムで乾燥し，エーテ ルを留去してオレイン酸系列の酸 $13.7 \mathrm{~g}$ を分離した。 他方アルコールロ液は塩酸で酸性とし, 水中に注加して エーテルで抽出し, 中性になるまで水洗した後, 無水硫 酸マグネシウムで乾燥してエーテルを留去してオレイン 酸系列以外の不飽和酸部 $63.2 \mathrm{~g}$ を分取した。てれらの 定数は Table-5 亿示す。

Table-5 Constants of oleic and other acids series.

\begin{tabular}{c|c|c|c|c}
\hline Series & $d_{4}^{25}$ & $n_{\mathrm{D}}^{25}$ & N.V. & I.V.(Wijs) \\
\hline Oleic acids & 0.9447 & 1.4614 & 191.3 & 96.1 \\
Other acids & 0.9297 & 1.4707 & 194.7 & 106.3 \\
\hline
\end{tabular}

\section{$2 \cdot 5$ 飽和酸部の検索}

$2 \cdot 3$ にて分離した飽和酸を常法によりメチルエステル
とした。すなわち飽和酸部 $9.0 \mathrm{~g}, 5 \%$ 塩化水素ーメタノ 一ル溶液の混合物を $6 \mathrm{hr}$ 還流し，メチルエステル $8.5 \mathrm{~g}$ を得た。その定数は酸価 2.3 , ケン化価 216.1 , ヨウ素 価（ウィイス法） 4.2 , 比重 $\left(d_{4}^{25}\right) 0.8889$, 屈折率 $\left(n_{\mathrm{D}}^{25}\right)$. 1.4512 であった。

このメチルエステルを管長 $9 \mathrm{~cm}$ の Widmer 氏の分 留塔を付した内容 $30 \mathrm{~m} l$ のフラスコに入れ 分留を行な った。分留は試料が少量のため 1 回だけとした。エステ ルの留出温度は Table-6 亿示すような範囲で分取した。

Table-6 Saturated acid methyl esters (Sample of the fractional distillation: $7.5 \mathrm{~g}$ ).

\begin{tabular}{|c|c|c|c|c|c|c|}
\hline $\begin{array}{c}\text { Frac- } \\
\text { tion } \\
\text { No. } \\
\end{array}$ & $\left|\begin{array}{r}\text { Temp. of } \\
\text { dist. }\left({ }^{\circ} \mathrm{C} / 6\right. \\
\mathrm{mmHg})\end{array}\right|$ & $\begin{array}{l}\text { Yield } \\
(\mathrm{g})\end{array}$ & A.V. & S.V. & $\underset{(\text { Wijs })}{\text { I.V. }}$ & Fatty acids detected \\
\hline 1 & $\sim 120$ & 0.4 & 4.7 & 309.7 & 3.3 & $\mathrm{C}_{8}, \mathrm{C}_{10}-$ Monobasic \\
\hline 2 & $120 \sim 135$ & 0.4 & 4.5 & 231.0 & 2.9 & $\begin{aligned} \mathrm{C}_{8}, \mathrm{C}_{10}, & \mathrm{C}_{12}, \mathrm{C}_{14}, \mathrm{C}_{16,}, \\
& \mathrm{C}_{18} \text {-Monobasic }\end{aligned}$ \\
\hline 3 & $135 \sim 142$ & 1.1 & 1.3 & 215.8 & 2.3 & $\begin{array}{r}\mathrm{C}_{10}, \mathrm{C}_{14}, \mathrm{C}_{16}, \mathrm{C}_{18^{-}} \\
\text {Monobasic }\end{array}$ \\
\hline 4 & $142 \sim 150$ & 1.0 & 1.0 & 207.5 & 2.6 & $\begin{array}{r}\mathrm{C}_{10}, \mathrm{C}_{14}, \mathrm{C}_{16}, \mathrm{C}_{18^{-}} \\
\text {Monobasic }\end{array}$ \\
\hline 5 & $150 \sim 155$ & 1.6 & 0.9 & 203.1 & 1.6 & $\mathrm{C}_{10}, \mathrm{C}_{16}, \mathrm{C}_{18-}^{-}$Monobasic \\
\hline 6 & $155 \sim 160$ & 1.5 & 1.1 & 199.2 & 2.6 & $\mathrm{C}_{10}, \mathrm{C}_{16}, \mathrm{C}_{18}-$ Monobasic: \\
\hline 7 & $160 \sim$ & 0.6 & 1.4 & 184.2 & 6.7 & $\mathrm{C}_{16}, \mathrm{C}_{18}$-Monobasic \\
\hline
\end{tabular}

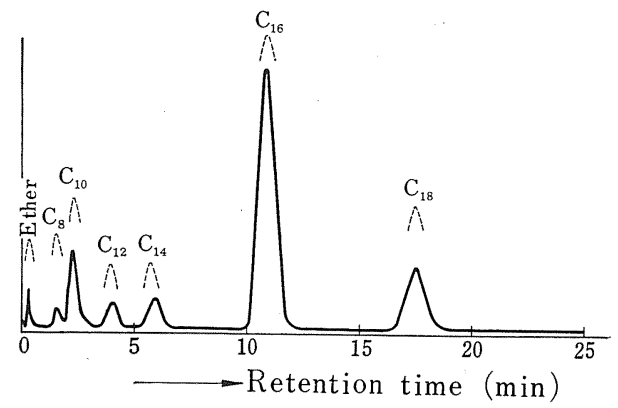

Fraction 2 . bp $120 \sim 135^{\circ} \mathrm{C} / 6 \mathrm{~mm} H$ Poly Ester D.S. $2 \mathrm{~m}$, Temp. $187^{\circ} \mathrm{C}$ . He $120 \mathrm{ml} / \mathrm{min}, \cdots \cdot$ : Standard sample

Fig.-1-A Gaschromatogram of saturated fatty acid methyl esters (Fraction 2).

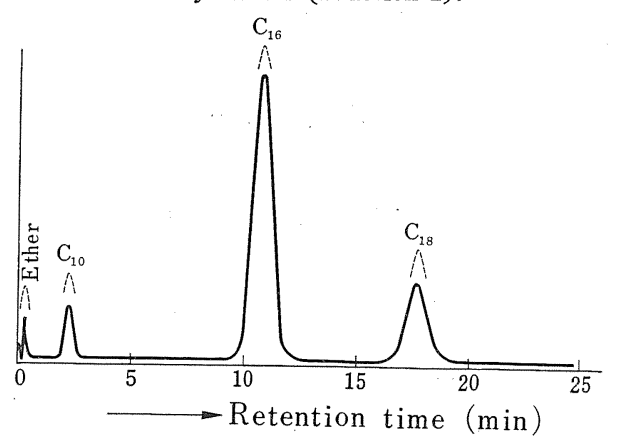

Fraction 5. bp $150 \sim 155^{\circ} \mathrm{C} / 6 \mathrm{~mm} H g$ Poly Ester D.S. $2 \mathrm{~m}$, Temp. $187^{\circ} \mathrm{C}$ He $120 \mathrm{~m} l / \mathrm{min}, \ldots .$. : Standard sample

Fig.-1-B Gaschromatogram of saturated fatty acid methyl esters (Fraction 5). 
各留分の定数を測定し，つづいてガスクロマトグラフィ 一にかけて検討した。同時にそれぞれの標準試料も行な い比較同定した。

Teble-6 には分留結果之検出脂肪酸，Fig.-1 には飽 和酸部のガスクロマトグラムの一例を示す。

以上の結果から各留分に存在する脂肪酸の数は多い上 うであるが，てれは留出温度範囲を少し広くとりすぎた ためと考光られ，また留出する各成分を同一アダプター にて分取したためとも考えられる。ガスクロマトグラフ ィーでの結果は各留分における各主成分のピークは大き

く、ほかに混在する成分のピークは小さかった。

すなわち飽和脂肪酸としてカプリル，カプリン，ラウ リン, ミリスチン, パルミチン, ステアリン酸の存在を 認めた。

\section{$2 \cdot 6$ 不飽和酸部の検索}

$2 \cdot 6 \cdot 1$ オレイン酸系列 : $2 \cdot 4$ で分離した試料を常法 そよりメチルエステルとし，2.5 の飽和酸メチルエステ ルを分留したものとまったく同じ装置で同様にして行な った。分留したものは定数を測定し,ガスクロマトグラ フィーにかけて検討した。これら結果を Teble-7 に示 す。

Table-7 Oleic acid series methyl esters (sample of the fractional distillation $: 10.0 \mathrm{~g}$ ).

\begin{tabular}{|c|c|c|c|c|c|c|}
\hline $\begin{array}{c}\text { Frac- } \\
\text { tion } \\
\text { No. }\end{array}$ & $\begin{array}{l}\text { Temp. of } \\
\text { dist. }\left({ }^{\circ} \mathrm{C} /\right. \\
8 \mathrm{mmHg})\end{array}$ & \begin{tabular}{|l|} 
Yield \\
$(\mathbf{g})$
\end{tabular} \mid & A.V. & S.V. & (W.V. & Fatty acids detected \\
\hline 1 & $\sim 145$ & 0.8 & 7.8 & 274.8 & 13.3 & $\mathrm{C}_{10}, \mathrm{C}_{12}, \mathrm{C}_{16}$-Monobasi \\
\hline 2 & $145 \sim 155$ & 0.8 & 0 & 237.1 & 22.0 & $\begin{array}{l}\mathrm{C}_{10}, \mathrm{C}_{12}, \mathrm{C}_{14}, \mathrm{C}_{16}, \mathrm{C}_{18} \mathrm{~F}_{1} \\
\text { Monobasic, unknown } \\
\text { Two pieces }\end{array}$ \\
\hline 3 & $155 \sim 165$ & 0.9 & 0 & 205.7 & 56.0 & $\begin{array}{l}\mathrm{C}_{14}, \mathrm{C}_{16}, \mathrm{C}_{18} \mathrm{~F}_{1}-\mathrm{Monoba} \\
\text { sic, unknown : Twc } \\
\text { pieces }\end{array}$ \\
\hline 4 & $165 \sim 175$ & 2.8 & 0 & 189.8 & 71.5 & $\begin{array}{l}\mathrm{C}_{16}, \mathrm{C}_{18} \mathrm{~F}_{1}-\text { Monobasic } \\
\text { unknown: One piece }\end{array}$ \\
\hline 5 & $175 \sim 198$ & 2.0 & 0 & 192.9 & 85.6 & $\mathrm{C}_{16}, \mathrm{C}_{18} \mathrm{~F}_{1}$-Monobasic \\
\hline 6 & $198 \sim 210$ & 1.7 & 6.3 & 185.5 & 69.7 & $\mathrm{C}_{18} \mathrm{~F}_{1}-$ Monobasic \\
\hline 7 & Residue & 0.8 & - & - & - & \\
\hline
\end{tabular}

cf) The residue is $0.8 \mathrm{~g}$ weight, but, also the distillation loss contained in this residue. Consequently, the actual residue was $0.4 \mathrm{~g}$ weight.

つぎにガスクロマトグラムの一例を Fig.-2 に示す。

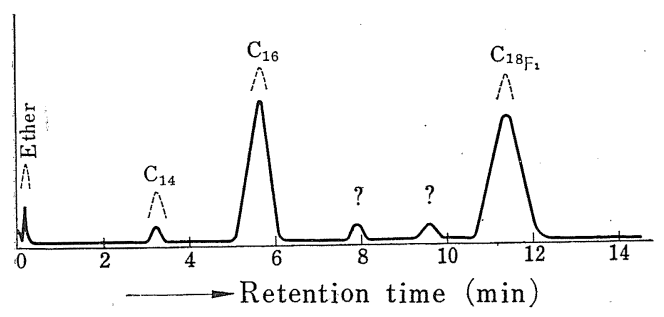

Fraction 3. bp $155 \sim 165^{\circ} \mathrm{C} / 8 \mathrm{mmHg}$ Poly Ester D.S. $2 \mathrm{~m}$, Temp. $200^{\circ} \mathrm{C}$ $\mathrm{He} 120 \mathrm{ml} / \mathrm{min}, \cdots \cdot$ : : Standard sample

Fig.-2-A Gaschromatogram of oleic acid series methyl esters (Fraction 3).

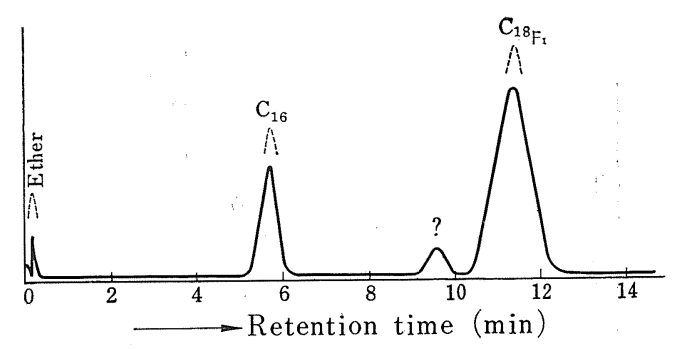

Fraction 4 . bp $165 \sim 175^{\circ} \mathrm{C} / 8 \mathrm{mmHg}$ Poly Ester D.S. $2 \mathrm{~m}$, Temp. $200^{\circ} \mathrm{C}$ He $120 \mathrm{ml} / \mathrm{m}$ in, $\cdots . .$. : Standard sample

Fig.-2-B Gaschromatogram of oleic acid series methyl esters (Fraction 4).

以上の結果からいくらかの飽和酸が存在するも主とし てオレイン酸であった。Teble-7からもかかるように分 留温度を少し広くとったために各留分に存在する成分の 数は多いように認められるが, ガスクロマトグラフィー の結果ではパルミチン酸ピーク以外に混在する飽和酸ピ ークはごく小さなものであった。また留分 2 および $3 に$ パルミチン酸ピークとオレイン酸ピークの中間に小さな 2 個のピークが認められ，リノール酸あるいはステアリ ン酸かと考えたが，一致せず少量で決定はできなかっ た。

つぎに主留分 4,5 はオレイン酸と認めたが，乙れを 確定するために留分 4 をケン化し, 遊離の酸とし, 四塩 化炭素に溶解, 水冷しながら臭素-四塩化炭素溶液を滴 加し, 臭化物として分離すれば $\mathrm{mp} 28 \sim 29^{\circ} \mathrm{C}$ であった。 てれはオレイン酸の二臭化物と一致した。 $\mathrm{Br}$ 分析值 35.9\% (オレイン酸二臭化物として計算值 $36.14 \%$ )。

っづいて留分 4 および 5 をそれぞれ $1.0 \mathrm{~g}$ とり， 1.5 \%水酸化ナトリウム溶液でケン化の後過マンガン酸カリ ウムで酸化を行ない, 白色のジオキシ酸を留分 4 からは $0.6 \mathrm{~g}$, 留分 5 からは $0.7 \mathrm{~g}$ を得た。いずれも $80 \%$ エタ ノールから再結晶し， mp 130 131 $\mathrm{C}$ のものを得た。

Table-8 Other acid series methyl esters (sample of the fractional distillation : $22.0 \mathrm{~g}$ ).

\begin{tabular}{|c|c|c|c|c|c|c|}
\hline $\begin{array}{l}\text { Frac } \\
\text { tion } \\
\text { No. }\end{array}$ & $\begin{array}{l}\text { Temp. of } \\
\text { dist. }\left({ }^{\circ} \mathrm{C} /\right. \\
9 \mathrm{mmHg})\end{array}$ & $\underset{(\mathrm{g})}{\text { Yield }}$ & A.V. & S.V. & $\begin{array}{l}\text { I.V. } \\
\text { (Wijs) }\end{array}$ & Fatty acids detected \\
\hline 1 & $\sim 140$ & 1.5 & 7.7 & 248,1 & 30.9 & $\begin{array}{l}\mathrm{C}_{10}, \mathrm{C}_{12}, \mathrm{C}_{14}, \mathrm{C}_{16}- \\
\text { Monobasic, unknown: } \\
\text { Two pieces }\end{array}$ \\
\hline 2 & $140 \sim 160$ & 1.1 & 0 & 225.5 & 41.5 & $\begin{array}{l}\mathrm{C}_{10}, \mathrm{C}_{12}, \mathrm{C}_{14}, \mathrm{C}_{16}, \mathrm{C}_{18} \mathrm{~F}_{1}- \\
\text { Monobasic, unknown: } \\
\text { Two pieces }\end{array}$ \\
\hline 3 & $160 \sim 170$ & 1.4 & 0 & 211.7 & 66.7 & $\begin{array}{l}\mathrm{C}_{10}, \mathrm{C}_{12}, \mathrm{C}_{14}, \mathrm{C}_{16}, \mathrm{C}_{18} \mathrm{~F}_{1-} \\
\text { Monobasic, unknown: } \\
\text { Two pieces }\end{array}$ \\
\hline 4 & $170 \sim 180$ & 5.6 & 0 & 199.7 & 103.0 & $\begin{array}{l}\mathrm{C}_{14}, \mathrm{C}_{16}, \mathrm{C}_{18} \mathrm{~F}_{1}, \mathrm{C}_{18} \mathrm{~F}_{2^{-}} \\
\text {Monobasic, unknown: } \\
\text { One piece }\end{array}$ \\
\hline 5 & $180 \sim 190$ & 7.8 & 0 & 193.4 & 110.1 & $\begin{array}{l}\mathrm{C}_{44}, \mathrm{C}_{16}, \mathrm{C}_{18} \mathrm{~F}_{1}, \mathrm{C}_{18} \mathrm{~F}_{2}- \\
\text { Monobasic, unknown: } \\
\text { One piece }\end{array}$ \\
\hline 6 & $190 \sim 200$ & 1.0 & 4.8 & 169.6 & 80.2 & $\begin{array}{l}\mathrm{C}_{14}, \mathrm{C}_{16}, \mathrm{C}_{18} \mathrm{~F}_{1}, \mathrm{C}_{18} \mathrm{~F}_{2-}^{-} \\
\text {Monobasic }\end{array}$ \\
\hline 7 & $200 \sim 220$ & 2.6 & 6.7 & 164.1 & 89.1 & $\mathrm{C}_{16}, \mathrm{C}_{18} \mathrm{~F}_{1}$-Monobasic \\
\hline 8 & Residue & 0.7 & - & -1 & - & - \\
\hline
\end{tabular}




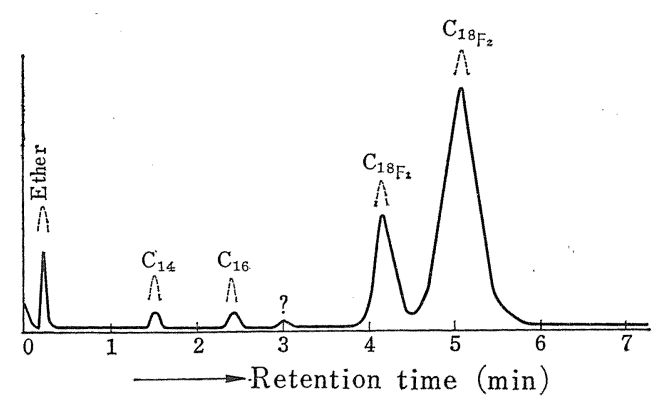

Fraction 5. bp $180 \sim 190^{\circ} \mathrm{C} / 9 \mathrm{~mm} H \mathrm{~g}$ Poly Ester D.S. $2 \mathrm{~m}$, Temp. $230^{\circ} \mathrm{C}$ He $120 \mathrm{~m} l / \mathrm{min}, \cdots-\cdots$ : Standard sample

Fig.-3 Gaschromatogram of other acid series methyl esters. (Fraction 5).

てれは 9,10-ジオキシステアリン酸と一致し, 別に標準 試料と混融し融点降下を認めなかった。

$2 \cdot 6 \cdot 2$ オレイン酸系列以外の酸系列：乙の酸系列を 常法によりメタノールと $5 \%$ 塩化水素から $55.0 \mathrm{~g}$ をメ チルエステルとなし，管長 $15 \mathrm{~cm}$ の Widmer 氏の分留 塔を付した $50 \mathrm{~m} l$ のフラスコに入れて 減圧下に分留し た。分留は 2 回行ない Table-8 に示すような温度範囲 で留出物を分取した。各留分の定数を測定し，ガスクロ マトグラフィーにかけて検討した。Teble-8 亿その結果 を示す。との系列のガスクロマトグラムの一例を Fig.-

3 飞示す。

以上の結果から各留分には数種の成分がガスクロマト グラフィーにより検出されたが，ての系列の主成分はり ノール酸であり，つづいてオレイン酸であった。飽和酸 はガスクロマトグラフィーのピークからみるとリノール 酸ピークに比してでく小さく，量的にはわずかであると 認められる。なお留分 $1 \sim 3$ に構造不明の酸を 2 個検出 したが量的にはわずかであり，いずれもオレイン酸系列 飞存在するものとまったく同一の $R_{t}$ であった。

つぎ主留分 $180 \sim 190^{\circ} \mathrm{C} / 9 \mathrm{mmHg} 3.0 \mathrm{~g}$ を水酸化ナ
トリウム溶液でケン化し， $2 \%$ 過マンガン酸カリウム水 溶液で酸化して mp 162 $164^{\circ} \mathrm{C}$ の白色結晶性物質を $1.9 \mathrm{~g}$ 得た。

てれは $9: 10,12: 13$-テトラオキシステアリン酸の 融点とよく一致した。別にりノール酸から合成した 9 : 10，12:13-テトラオキシステアリン酸と混融し, 融点 降下を示さなかった。第 2 結晶として融点の低い $\mathrm{mp}$ $122 \sim 158^{\circ} \mathrm{C}$ のものが得られたが，乙れは前記テトラオ キシステアリン酸とシオキシステアリン酸の混合物と考 光られ。

なお 2.5，2.6 の検索から 2.3，2.4 における分離に おいていくら”办の飽和酸が不飽和酸部に, またオレイン 酸系列のものはオレイン酸系列以外の酸系列に混在し, 分留の際にも前記のように Widmer 氏の分留塔を使用 したために各酸部および各酸系列の分留が多少不十分と なり，ガスクロマトグラフィーによって少量成分まで検 出されたものと考觉られる。

\section{3 総括}

土佐産せんだんの実の油脂構成脂肪酸を検討し，主成 分はパルミチン酸, オレイン酸, リノール酸で, 少量成 分としてカプリル酸, カプリン酸, ラウリン酸, ミリス チン酸,ステアリン酸の存在を認めた。なおガスクロマ トグラフィーの結果， $\mathrm{C}_{16}$ あるいは $\mathrm{C}_{18}$ - 酸と考元られ る脂肪酸も存在すると認めたが，構造を確定するに至ら なかった。

またてれら構造不明の酸および各脂肪酸の量的関係に ついては今後さらに検討してみたいと考光ている。

日本化学会中四国支部常会にて講演 昭 38.10 (昭和 39 年 10 月 17 日受理)

$$
\text { 文献 }
$$

1) 西田, 金田, 林学, No.9, 3, 9 (昭 2)

2) 三浦, 工化, 26, 570 (大 12)

3) 三浦, 工化, 25. 1286 (大 11)

4）吉村, 古賀, 鹿児島高農学術報告, 4, 47 (大 10)

\title{
癌 組 織 の 脂 質 (第 3 報) \\ 油脂化学の立場からみた癌発生原因の一考察
}

\author{
福 住 一 雄 \\ 名古屋大学工学部応用化学教室 (名古屋市千種区不老町)
}

Lipids of Cancerous Tissue. III.

The Speculation on the Cause of Cancer Generation from the Viewpoint of Fat Chemistry Kazuo Fukuzumi

Department of Applied Chemistry, Faculty of Engineering, Nagoya University

(Furō-chō, Chigusa-ku, Nagoya)

It may be inferred that if oxidized lipids would form complexes with nucleoproteins of cells, the 